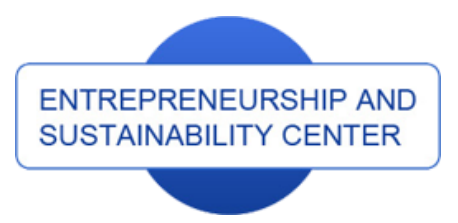

Publisher

http://jssidoi.org/esc/home
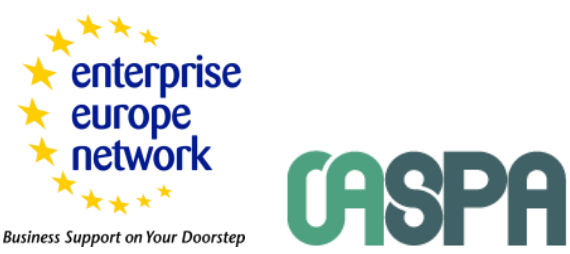

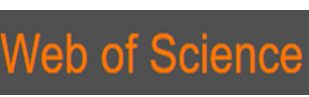

\title{
ECONOMIC DEVELOPMENT OF COMMUNITY BY ENTREPRENEURSHIP: AN INVESTIGATION OF THE ENTREPRENEURIAL INTENT AND THE INSTITUTIONAL SUPPORT TO THE LOCAL COMMUNITY IN AL-KHARJ REGION*
}

\author{
Mohammad Naushad', Mohammad Rishad Faridi² ${ }^{2}$ and Syed Abdul Malik ${ }^{3}$ \\ ${ }^{1,2,3}$ College of Business Administration, Prince Sattam Bin Abdulaziz University, Al-Kharj, Kingdom of Saudi Arabia \\ E-mails:느.mohammad@psau.edu.sa; ${ }^{2}$ m.faridi@psau.edu.sa; ${ }^{3}$ a.syed@psau.edu.sa
}

Received 12 February 2018; accepted 10 May 2018; published 30 June 2018

\begin{abstract}
The purpose of the present study is twofold, to investigate the entrepreneurial intent of the university students and to chalk out with the factors (educational) to be considered for institutional support by the university under study. The Theory of Planned Behavior (TPB) questionnaire was adopted and administered along with a separate sixteen items sheet containng the items pertaining to the institutional suppot mechanisms. Overall, 370 responses were collected from both male \& female students. The Data was analysed by applying correlations, linear and hierarchical regression and exploratory factor analysis (EFA). The results of the study reaffirm the theory of planned behaviour in Saudi context with a significant variance of 43.2 percent in explaining students' entrepreneurial intent. However, in the present case it is found that both attitude and perceived behavioral control are the significant predictors of entrepreneurial intent. Moreover, the subjective norm did not significantly predict the entrepreneurial intent. The findings also suggest a four steps generic model of institutional educational support for entrepreneurial nurturement to the local community.
\end{abstract}

Keywords: Entrepreneurial intent; Theory of Planned behaviour; Economic Development; Institutional Support; Al-Kharj region

Reference to this paper should be made as follows: Naushad, M.; Faridi, M.R.; Malik, S. A.; 2018. Economic development of community by entrepreneurship: an investigation of the entrepreneurial intent and the institutional support to the local community in Al-Kharj region, Entrepreneurship and Sustainability Issues 5(4): 899-913. http://doi.org/10.9770/jesi.2018.5.4(14)

JEL Classifications: L26, O10, C20

\footnotetext{
"We are grateful to the Deanship of Scientific Research at Prince Sattam Bin Abdulaziz University for financing this study under the research project \# 2015/02/4862.
} 


\section{Introduction}

The effect of entrepreneurship on unemployment reduction, income generation and economic prosperity is observed and examined by many studies like Birch (1983), McMullan and Long (1987), Thurik (2003) and Baptista and Thurik (2007), etc. There is a consensus among management practitioners and researchers that successful new ventures are the contributing factors to employment that leads to political and social stability, innovation and competition (Khan, 2013). Undoubtedly, entrepreneurship is something that has to be nurtured within the country itself. In this context it is noticed that educational institutions play a vital role in providing trained workforce; new knowledge creation; support to the existing research and innovation; knowledge transfer; attractor of new talent etc. (Gertler \& Vinodrai, 2005; Kirby, 2006). Universities are not only considered as the producers and disseminators of new knowledge (Guerrero \& Urbano, 2012) but they are also instrumental in regional, economic and social development (Bygrave \& Minniti, 2000; Kirby et al., 2011). In the present knowledge economy, universities are more focused towards promoting the entrepreneurial culture among the community and industries as a whole (Abreu et al., 2016; Kirby et al., 2011). There is evidence worldwide where a significant relationship between the support provided by universities and the level of entrepreneurial activities can be cited easily (Coduras et al., 2008). A University could be primarily a dedicated entrepreneurial university, oriented towards innovation and entrepreneurial culture (Kirby, 2006) or it can be a simply an educational institution with a distinct vision and mission (other than entrepreneurship) but also having some inclination towards entrepreneurship.

The second type of institution is the focal point in the present study. Up to what extent and how a primarily teaching and secondarily research focused regional university can contribute and support in the entrepreneurial development of the local community. The present study has a twofold aim: (1) to measure the level of entrepreneurial intent among the selected and targeted community. i.e. confined to Al-Kharj region of Saudi Arabia; (2) to investigate and suggest the supportive measures required to uplift or nourish the entrepreneurial culture among the community as a whole.

\section{Review of Existing literature on Entrepreneurial intent and hypothesis setting}

Successful entrepreneurship is considered as an offshoot of entrepreneurial intent. According to Bird (1988), "entrepreneurial intention refers to the individual state of mind that aimed at creating new ventures, developing a new business concept or creating new value within existing firm". Researchers show that intentions can be cultivated and inspired by providing the educational and other kinds of support needed for successful entrepreneurial activities (Matlay, 2008; Støren, 2014). Studies like Engle et al. (2011) suggests that institutional supports in a variety of ways is much desirable and needed to influence and nourish the entrepreneurial intent and for the successful development of entrepreneurship. Though explaining human behaviour in all its complexity is a difficult task (Ajzen, 1991). The theory of planned behaviour has been proven to predict the behaviour by utilising its antecedent. Intention to perform behaviour of different kinds can be predicted with high accuracy from attitudes, subjective norms and perceived behavioural control (Ajzen, 1991; Ajzen, 2002). Intentions are assumed to capture the motivational factors that influence the behaviour. Intentions reflect the level of efforts of individuals to perform a particular behaviour. The three constructs namely, attitude toward the behaviour, subjective norm, and perception of behavioural control mentioned by Ajzen are the core of TPB. While combining these three constructs will lead to the formation of a behavioural intention (Ajzen, 2002).

One of the constructs out of the three independent constructs is the attitude towards a particular behaviour. Attitude is termed as the favourable or unfavourable appraisal of the conduct in question (Ajzen \& Fishbein, 2005). It is because the attitude can be positive or negative towards some events or the things. While attitude was 
tested in the context of entrepreneurial intent or behaviour, it is found to be positive in the cross country studies (Iakovleva et al., 2011; Nabi et al., 2011). Attitude is one' personal construct belong to personality while Subjective norm is a social construct refers to the social pressure. Subjective norm refers to the perceived social behaviour to perform or not to perform the behaviour (Ajzen, 1991). People are likely to engage in entrepreneurship when their socially build environment is favourable specifically the people surrounding them (Liñán, 2008; Radwan, Sakr, 2017). Subjective norms found to be a significant predictor of entrepreneurial intent in numerous studies like Kolvereid (1996); Krueger et al. (2000); Schwarz et al. (2009); van Gelderen et al. (2008); Schlaegel and Koenig (2014), etc. The third construct that constitutes the intention is the degree to the perceived behavioural control. It refers to the perceived ease or difficulty of performing the behaviour (Ajzen, 1991). The level of PBC depends upon the self-confidence to do the specific behaviour and availability of resources needed or assisting in performing the behaviour (Ajzen, 1991; Liñán \& Chen, 2006; van Gelderen et al., 2008). As a rule of thumb as mentioned in the TPB (Ajzen, 1991) that "the more favourable the attitude and subjective norm concerning a behaviour, and the greater the perceived behavioural control, the stronger should be an individual's intention to perform the behaviour under consideration." Theory of planned behaviour has been applied successfully in different context and culture. In Saudi Context also it has been implemented by very few researchers only, and that too also rendered the mixed results. Table-1 provides the summary of studies conducted in Saudi context, specifically applying the TPB.

Thus the present study is significant in two ways (i) to reaffirm the results of earlier studies on TPB by taking a different sample base. (ii) to Come up with the mechanism of institutional support to nurture the antecedents of TPB which seems to be predicting the behavior of Saudi students.

Table 1. Summary of Existing literature of Theory of Planned Behavior (TPB) in Saudi Arabia

\begin{tabular}{|c|c|c|c|c|c|}
\hline S.N. & Authors & Approach & Sample & Tools Used & Major Findings \\
\hline 1 & Aloulou (2016) & TPB & $\begin{array}{l}177 \\
\text { undergraduate } \\
\text { students of a } \\
\text { public } \\
\text { University }\end{array}$ & $\begin{array}{l}\text { Multiple, } \\
\text { Linear and } \\
\text { Hierarchical } \\
\text { Regression }\end{array}$ & $\begin{array}{l}\text { Overall the antecedent of } \\
\text { TPB significantly explain } \\
33.4 \% \text { of the variance in } \\
\text { students Intention. } \\
\text { SN has a stronger influence } \\
\text { than other antecedents on } \\
\text { the intention. }\end{array}$ \\
\hline 2 & Ali (2016) & TPB & $\begin{array}{l}283 \text { final year } \\
\text { business } \\
\text { students of a } \\
\text { public } \\
\text { University }\end{array}$ & $\begin{array}{l}\text { Hierarchical } \\
\text { Multiple } \\
\text { Regression }\end{array}$ & $\begin{array}{l}\text { All the antecedents of EI } \\
\text { Significantly explain } 40 \% \\
\text { of the variance in EI. } \\
\text { Attitude Explain the } \\
\text { highest Variance, i.e. } 33.8 \\
\text { followed by PBC } 32 \% \text { and } \\
\text { SN explained the least, i.e. } \\
8.5 \% \text {. }\end{array}$ \\
\hline
\end{tabular}




\begin{tabular}{|c|l|l|l|l|l|}
\hline 3 & $\begin{array}{l}\text { Almobaireek } \\
\text { and Manolova } \\
(2012)\end{array}$ & TPB & $\begin{array}{l}950 \\
\text { undergraduate } \\
\text { Saudi male and } \\
\text { female students } \\
\text { logistic } \\
\text { regression } \\
\text { model }\end{array}$ & $\begin{array}{l}\text { Attitude and PBC found } \\
\text { the association with EI, } \\
\text { however, there was no } \\
\text { significant association } \\
\text { between therceived } \\
\text { social normand EI. } \\
\text { PBC is the most consistent } \\
\text { predictor of EI. } \\
\text { Attitude Explain the EI } \\
\text { strongly. } \\
\text { While SN has the lowest } \\
\text { among others. }\end{array}$ \\
\hline 4 & $\begin{array}{l}\text { (Iqbal et al., } \\
2012)\end{array}$ & TPB & $\begin{array}{l}292 \text { randomly } \\
\text { selected } \\
\text { students from a } \\
\text { private } \\
\text { University }\end{array}$ & $\begin{array}{l}\text { Multiple } \\
\text { Regression } \\
\text { explains significant and } \\
\text { among its antecedent. } \\
\text { Other Variables are related, } \\
\text { but SN has the lowest } \\
\text { significance. }\end{array}$ \\
\hline
\end{tabular}

Source: Researcher's compilations

\section{Hypothesis Setting:}

To test the TPB among the sample of Saudi students, the following hypothesis can be stated

$\boldsymbol{H}_{1}$ : The entrepreneurial antecedents of TPB positively influence the Entrepreneurial intent of students.

$\boldsymbol{H}_{\text {Ia: }}$ : The perceived attitude to perform the entrepreneurship positively influence the Entrepreneurial intent of students.

$\boldsymbol{H}_{l b}$ : The perceived Subjective Norm positively influences the Entrepreneurial intent of students.

$\boldsymbol{H}_{\boldsymbol{l} \boldsymbol{c}}$ : The perceived behavioural control positively affect the Entrepreneurial intent of students.

Perceived behavioral attitude is considered a good predictor of entrepreneurial intent in Arab Context. Studies like, Aloulou (2016); Khalifa and Dhiaf (2016); Almobaireek and Manolova (2012); Majumdar and Varadarajan (2013) etc. found that attitude significantly and constatntly predict the entrepreenurial intent of Arab students. Therefore, A possiblity of attitudinal impact on ther antecedents of TPB can not be overlooked. Thus, the second hypothesis can be stated as:

$\boldsymbol{H}_{2}$ : The Perceived attitude to perform entrepreneurship positively influence other antecedent of TPB.

$\boldsymbol{H}_{2 a}:$ The perceived attitude to perform entrepreneurship positively influence the Subjective norm.

$\boldsymbol{H}_{2 b}$ : The perceived attitude to perform entrepreneurship positively influence the perceived behavioural control of students.

Researchers like, Mustafa et al. (2016); Aloulou (2016); Turker and Sonmez Selcuk (2009) etc. have taken the demographic variable as the control variable to the entrepreneurial intent. We have also used the four different variables (gener, age, educational background and family business background) as control variables to regress over the entrepreneurial intent. Thus, the third hypothesis can be stated as:

$\boldsymbol{H}_{3}$ : The Demographic Variables like Gender, age, educational background and family business background positively influence the Entrepreneurial intent of students. 


\section{Methodology}

The study is based on the primary data collected by administering the survey instrument adopted from (Liñán \& Chen, 2009) for entrepreneurial intent antecedents and institutional support or educational support variables from (Saleh \& Salhieh, 2014). The questionnaire was translated into Arabic language and administered in Arabic. The population selected for the survey was business students who were in level five and above (Bachelor of Science in Business Administration (BSBA) program has total eight levels) of Prince Sattam bin Abdulaziz University registered in different campuses. Notably, our focus here is not about the antiquities of an entrepreneurial research university but to explore the dimension of support by a newly established public university to the local community to support and promote their entrepreneurial intentions. Moreover, ultimately helping them to transform into the entrepreneurial behaviour. Here, we try to investigate the perception of the local community about the perceived support from a newly established university, has a vision of community services/partnership and which is primarily a teaching based university.

The questionnaire was administered for about 500 students in paper and pencil form. 370 responses were collected from both male $\&$ female students. This overall constitute the effective rate of 74 percent. An intensive care was taken to validate the data for analysis. Missing values were checked before the final analysis. The major missing responses were eradicated while the responses with less missing frequencies were replaced with the series mean. The Outliers were detected with interquartile range (IQR) and box plotting using SPSS. The identified outlier was totally removed from the data. By this way, the total number of usable items for final analysis were 304. Table-2 below presents the characteristics of the sample used in the study.

Table 2. Characterstics of Samples

\begin{tabular}{|l|l|}
\hline \multicolumn{1}{|c|}{ Data Type } & \multicolumn{1}{c|}{ Questionnaire administered data } \\
\hline Population & Level 5 and Above Business Undergraduate Students \\
\hline Sample Size & 370 \\
\hline Response Rate & 74 percent \\
\hline Final Data for Analysis & 304 \\
\hline Male Respondents & 214 \\
\hline Female Respondents & 90 \\
\hline
\end{tabular}

Table-3 provides the snapshot of the demographic characteristics of the population. The Cronbach's alpha for all the items of TPB was calculated together, i.e. 0.767 which is above than the reliability threshold.

Table 3. Demographic and other characteristics of Population

\begin{tabular}{|l|l|}
\hline $\begin{array}{c}\text { Demographic and other } \\
\text { Background Variables }\end{array}$ & \multicolumn{1}{c|}{ Data classification- Frequency $(\boldsymbol{n})$ \& Percentage $(\%)$} \\
\hline Gender & Male $=214(70 \%)$, Female $=90(30 \%)$. \\
\hline Age Group & Below 20 Years $=24(7.9 \%) ; 21-24$ Years $=257(84.5 \%) ; 25$ years and above $=23(7.6 \%)$. \\
\hline Specialization & Accounting $=85(28 \%) ;$ Finance $=59(19.4 \%) ;$ HRM = 108 (35.5\%); MIS 52 (17.1\%). \\
\hline Family Business Background & Yes $=155(51 \%) ; \mathrm{No}=149(49 \%)$. \\
\hline
\end{tabular}




\section{Results and Discussions}

The Table-4 explains the descriptive statistics of the TPB antecedents. Where the mean score for E_Intent is 5.988 $(\mathrm{M}=5.988, \mathrm{SD}=.988)$, the other antecedent has a mean ATTD $(M=5.896, S D=.823), \mathrm{S} \_$Norm $((M=5.279, S D$ $=1.049), \mathrm{PBC}(M=4.921, S D=1.260)$ respectively.

Table 4. Descriptive Statistics

\begin{tabular}{|l|c|c|c|c|c|c|c|c|c|}
\hline & N & Min. & Max. & Mean & Std. Dev. & \multicolumn{2}{|c|}{ Skewness } & \multicolumn{2}{|c|}{ Kurtosis } \\
\cline { 2 - 10 } & Stat. & Stat. & Stat. & Stat. & Stat. & Stat. & $\begin{array}{c}\text { Std. } \\
\text { Error }\end{array}$ & Stat. & $\begin{array}{c}\text { Std. } \\
\text { Error }\end{array}$ \\
\hline E_Intent & 304 & 2.75 & 7.00 & 5.9885 & .98873 & -.908 & .140 & .044 & .279 \\
\hline ATTD & 304 & 3.00 & 7.00 & 5.8967 & .82325 & -.726 & .140 & .247 & .279 \\
\hline S_Norm & 304 & 1.50 & 7.00 & 5.2796 & 1.04949 & -.330 & .140 & -.221 & .279 \\
\hline PBC & 304 & 1.33 & 7.00 & 4.9216 & 1.26081 & -.412 & .140 & -.323 & .279 \\
\hline $\begin{array}{l}\text { Valid N } \\
\text { (listwise) }\end{array}$ & 304 & & & & & & & & \\
\hline
\end{tabular}

Table 5. Correlation Matrix

\begin{tabular}{|c|c|c|c|c|c|c|c|c|c|}
\hline Spearman's rho & 1 & 2 & 3 & 4 & 5 & 6 & 7 & 8 & 9 \\
\hline 1- E_Intent & 1.000 & & & & & & & & \\
\hline \multirow[t]{2}{*}{ 2- ATTD } & $.617^{* * *}$ & 1.000 & & & & & & & \\
\hline & .000 & & & & & & & & \\
\hline \multirow[t]{2}{*}{ 3- S_Norm } & $.390^{* *}$ & $.382^{* *}$ & 1.000 & & & & & & \\
\hline & .000 & .000 & & & & & & & \\
\hline \multirow[t]{2}{*}{ 4- PBC } & $.477^{* *}$ & $.432^{* * *}$ & $.523^{* *}$ & 1.000 & & & & & \\
\hline & .000 & .000 & .000 & & & & & & \\
\hline \multirow[t]{2}{*}{ 5- GENDER } & -.060 & -.070 & .067 & -.007 & 1.000 & & & & \\
\hline & .296 & .226 & .248 & .899 & & & & & \\
\hline \multirow[t]{2}{*}{ 6- AGE GROUP } & .037 & .059 & .042 & .053 & $-.269^{* *}$ & 1.000 & & & \\
\hline & .525 & .308 & .466 & .354 & .000 & & & & \\
\hline \multirow[t]{2}{*}{ 7- COURSE CURRENTLY PURSUING } & -.107 & -.083 & .020 & -.001 & $.145^{*}$ & .002 & 1.000 & & \\
\hline & .063 & .146 & .734 & .985 & .011 & .976 & & & \\
\hline \multirow[t]{2}{*}{ 8- SPECIALIZATION } & -.095 & -.057 & -.011 & -.071 & $-.197^{* *}$ & $.116^{*}$ & $.222^{* *}$ & 1.000 & \\
\hline & .098 & .318 & .845 & .216 & .001 & .043 & .000 & & \\
\hline \multirow[t]{2}{*}{ 9- FAMILY BUSINESS BACKGROUND } & $-.140^{*}$ & $-.143^{*}$ & -.082 & $-.126^{*}$ & $-.160^{* *}$ & .008 & .021 & .075 & 1.000 \\
\hline & .015 & .013 & .153 & .028 & .005 & .887 & .719 & .192 & \\
\hline
\end{tabular}


The International Journal

ENTREPRENEURSHIP AND SUSTAINABILITY ISSUES

ISSN 2345-0282 (online) http://jssidoi.org/jesi/

2018 Volume 5 Number 4 (June)

http://doi.org/10.9770/jesi.2018.5.4(14)

Before delving into the regression analysis, a spearman correlation among all the variables was selected in order to carry out the study. The Entrepreneurial intent (E_intent) was found that it has a statistically significant correlation with the perceived attitude towards behaviour (ATTD), Perceived subjective norm (S_Norm) and Perceived Behavioural control (PBC). There was no significant difference of entrepreneurial intent and its antecedent regarding gender (male/female) was cited. On the other hand, those with a family business background have a significant amount of correlation with entrepreneurial intent, and its antecedent. Table-5 above explains the results of correlations in details.

A multiple linear regression was carried out to know the predictability of TPB (entrepreneurial intent and its' antecedent $)$ in the Saudi context. It was found to be significant with a regression equation $(\mathrm{F}(3,300)=76.118, p<$ .000 ), with an $R^{2}$ of .432 and $R^{2}$ Adjusted $=.427$. Respondents' predicted Entrepreneurial Intent is equal to $1.310-$ $.583+.073+.174$, where all the Independent Variables (IVs) are measured on a seven-point Likert scale. It was found that both attitude and perceived behavioural control are the significant predictors of entrepreneurial intent. However, the subjective norm did not significantly predict the entrepreneurial intent $(\beta=.077, \mathrm{t}(303)=1.493$, ns).

The collinearity statistics show no evidence of multicollinearity as measured by Variance Inflation Factor (VIF). The tests indicated a very low level of multicollinearity, $\left(V I F=1.327, A T T D ; 1.413\right.$ for $S \_$Norm and 1.423 for $P B C)$. The VIF in all the cases is $>1$ but less than 2 .

Though there is no formal VIF value for determining the presence of multicollinearity but the lesser value of VIF not exceeding ten is considered as safe. Thus, the results discussed below in Table-6 support the hypothesis $\boldsymbol{H}_{\boldsymbol{l}}$, $\boldsymbol{H}_{1 a}$, and $\boldsymbol{H}_{1 c}$. However, hypothesis $\boldsymbol{H}_{1 b}$ did not find any support for acceptance.

Table 6. Regression Results for Hypothesis 1

\begin{tabular}{|c|c|}
\hline DV-E_Intent & STd. $\beta$ \\
\hline \multicolumn{2}{|l|}{$I V:$} \\
\hline 1. ATTD & $.486^{* * *}$ \\
\hline 2. $\quad$ S_Norm & $.077^{\mathrm{ns}}$ \\
\hline 3. $P B C$ & $.222^{* *}$ \\
\hline $\mathrm{R}$ & $.657 \mathrm{a}$ \\
\hline $\mathrm{R}^{2}$ & 0.432 \\
\hline Adjusted $\mathrm{R}^{2}$ & 0.426 \\
\hline$\Delta \mathrm{R}^{2}$ & .432 \\
\hline $\mathrm{F}$ & 76.118 \\
\hline$\Delta \mathrm{F}$ & 76.118 \\
\hline Significance of $\mathrm{F}$ & $0.000^{* * *}$ \\
\hline Targeted Hypotheses & $H_{l a}-H_{l c}$ \\
\hline \multicolumn{2}{|c|}{ Notes: $\mathrm{n}=304 . * *$ Significant at 0.01 level $(p<0.01)$} \\
\hline \multicolumn{2}{|c|}{$\begin{array}{l}\text { Annotations: } D V=\text { Dependent Variable, IV= Independent Varible, E_Intent= Entrepreneurial } \\
\text { Intent, ATTD }=\text { Attitude Towards the behavior, S_Norm= Subjective Norm, PBC= Perceived } \\
\text { Behavioral Control. }\end{array}$} \\
\hline
\end{tabular}


The International Journal

ENTREPRENEURSHIP AND SUSTAINABILITY ISSUES

ISSN 2345-0282 (online) http://jssidoi.org/jesi/

2018 Volume 5 Number 4 (June)

http://doi.org/10.9770/jesi.2018.5.4(14)

To test our second hypotheses, a multiple linear regression test was carried out separately for the antecedents, where SN has been taken as the dependent variable. When ATTD is taken as IV the significant regression equation emerged as $(\mathrm{F}(1,302)=66.309, p<0.000)$, with an $R^{2}$ of 0.180 and $R^{2}{ }_{\text {Adjusted }}=0.177$ (Table 7).

Moreover, the another regression equation, when PBC was taken as an $I V$ emerged as $(\mathrm{F}(1,302)=69.132, p<$ 0.000 ), with an $R^{2}$ of 0.186 and $R^{2}$ Adjusted $=0.183$ indicating that attitude is significantly impacting equally (with minor, negligible difference) with the other antecedents of TPB. (Table 8).

Table 7. Regression Results for Hypothesis 2

\begin{tabular}{|c|c|c|}
\hline & $\begin{array}{c}D V-S N \\
\text { STd. } \beta\end{array}$ & $\begin{array}{l}D V-P B C \\
\quad S T d . \beta\end{array}$ \\
\hline IV: ATTD & $.541^{* *}$ & $.661^{* *}$ \\
\hline $\mathrm{R}$ & .424 & .432 \\
\hline $\mathrm{R}^{2}$ & 0.180 & 0.186 \\
\hline Adjusted $\mathrm{R}^{2}$ & 0.177 & 0.184 \\
\hline$\Delta \mathrm{R}^{2}$ & 0.180 & 0.186 \\
\hline $\mathrm{F}$ & 66.308 & 69.132 \\
\hline$\Delta \mathrm{F}$ & 66.308 & 69.132 \\
\hline Significance of $F$ & 0.000 & 0.000 \\
\hline Targeted Hypotheses & $H_{2 a}$ & $H_{2 b}$ \\
\hline \multicolumn{3}{|c|}{ Notes: $\mathrm{n}=304 . * *$ Significant at 0.01 level $(p<0.01), n s=$ Not Significant } \\
\hline \multicolumn{3}{|c|}{$\begin{array}{l}\text { Annotations: } D V=\text { Dependent Variable, } I V=\text { Independent Varible, } A T T D=\text { Attitude Towards the } \\
\text { behavior, } S \_ \text {Norm }=\text { Subjective Norm, } P B C=\text { Perceived Behavioral Control. }\end{array}$} \\
\hline
\end{tabular}

Thus, the results discussed above provide the support for the hypotheses $\left(\mathrm{H}_{2}, \mathrm{H}_{2 \mathrm{a}}\right.$ and $\left.\mathrm{H}_{2 b}\right)$

To test the hypothesis that the demographic variables like gender, age, educational background and family business background positively influence the entrepreneurial intent of students; a hierarchical multiple regression analysis was performed. As a first step regression on TPB antecedents were carried out. The antecedents have also repeated the same trend here and were still found to be statistically significant, where ATTD $\left(_{\beta}=.486 ; \mathrm{t}=9.688\right.$; $\mathrm{p}<.001)$, S_Norm $\left.\left({ }_{\beta}=.077 ; \mathrm{t}=1.493 ; \mathrm{p}=1.493 \mathrm{~ns}\right), \mathrm{PBC}_{\beta}=.222 ; \mathrm{t}=4.270 ; \mathrm{p}<.001\right)$. At the time of combining these variables with the demographic variables as a second step the model fit has increased $\left(R=.444, R^{2}=.429, \mathrm{~F}\right.$ $(8,295)=29.425, \mathrm{p}<.001)$ that means addition of the demographic variables improve the prediction of the model. However, the individual coefficients of the demographic variables are found to be insignificant. 
Table 8. Regression Results for Hypothesis 3

\begin{tabular}{|c|c|c|c|c|}
\hline \multicolumn{5}{|l|}{ DV-E_Intent } \\
\hline & $\boldsymbol{B}$ & $S E b$ & $\begin{array}{c}\text { Std. } \beta \\
(\text { Step 1) }\end{array}$ & $\begin{array}{c}\text { Std. } \beta \\
(\text { Step 2) } \\
\end{array}$ \\
\hline \multicolumn{5}{|l|}{ STEP 1} \\
\hline Constant & 1.310 & .325 & - & - \\
\hline$A T T D$ & .583 & .060 & $.486^{* *}$ & - \\
\hline S_Norm & .073 & .049 & $.077^{\mathrm{ns}}$ & - \\
\hline$P B C$ & .174 & .041 & $.222^{* *}$ & - \\
\hline \multicolumn{5}{|l|}{ STEP 2} \\
\hline Constant & 2.010 & .496 & - & - \\
\hline$A T T D$ & .561 & .061 & - & $.467^{* *}$ \\
\hline$S \_N O R M$ & .081 & .049 & - & $.086^{\mathrm{ns}}$ \\
\hline$P B C$ & .171 & .041 & 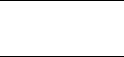 & $.218^{* *}$ \\
\hline Gender & -.069 & .103 & - & $-.032^{\mathrm{ns}}$ \\
\hline Age Group & -.039 & .114 & - & $-.016^{\mathrm{ns}}$ \\
\hline Course currently pursuing & -.153 & .114 & - & $-.061^{\mathrm{ns}}$ \\
\hline Specialization & -.056 & .042 & - & $-.060^{\mathrm{ns}}$ \\
\hline Family business background & -.088 & .088 & - & $-.045^{\mathrm{ns}}$ \\
\hline $\mathrm{R}$ & - & - & .657 & .666 \\
\hline $\mathrm{R}^{2}$ & - & - & 0.432 & 0.443 \\
\hline Adjusted $\mathrm{R}^{2}$ & - & - & 0.426 & 0.428 \\
\hline$\Delta \mathrm{R}^{2}$ & - & - & 0.432 & 0.011 \\
\hline $\mathrm{F}$ & - & - & 76.117 & 1.232 \\
\hline$\Delta \mathrm{F}$ & - & - & 76.117 & 1.232 \\
\hline Significance of F & - & - & 0.000 & 0.294 \\
\hline Targetted Hyotheses & \multicolumn{4}{|l|}{$H 3$} \\
\hline \multicolumn{5}{|c|}{$\begin{array}{l}\text { Notes: } \mathrm{n}=304 .{ }^{*} \text { Significant at } 0.01 \text { level }(p<0.01), n s=\text { Not Significant, } \\
\text { Annotations: } D V=\text { Dependent Variable, IV=Independent Varible, E_Intent }=\text { Entrepreneurial Intent, } \\
A T T D=\text { Attitude Towards the behavior, S_Norm= Subjective Norm, PBC=Perceived Behavioral Control. }\end{array}$} \\
\hline
\end{tabular}

In this section, an attempt has been made to investigate and identify the factors that can be fruitful to streamline the institutional support from the education perspectives. To collect the student's perspectives from an educational point of view, a sixteen items questionnaire adopted from Saleh and Salhieh (2014) was administered as an integral component of the TPB questionnaire on a seven-point likert scale. A total of 304 questionnaires were used for the analysis. However, before executing the factor analysis, an intensive care was taken to validate the data reliability. High volume missing values were eradicated, and low-level missing values were replaced with series mean. The Cronbach's alpha for these items were calculated separately, i.e. 0.961 which is highly reliable. 
Outliers were detected with interquartile range (IQR) and box plotting using SPSS. The identified outliers were removed from the data. By this way, the total number of usable items for factor analysis was 304 .

Before proceeding with the exploratory factor analysis (EFA) sampling adequacy was checked with KaiserMeyer-Ohlin (KMO) and sphericity with Barlett's test. The KMO was found to be 0.948 , indicating that data is highly sufficient and justified for the EFA. The sphericity test is also found to be significant.

As a second step, exploratory factor analysis (EFA) using Principal Axis Factoring and Non-Orthogonal Promax rotation with Kaiser Normalization (Eigenvalues $\geq 1$ ) was conducted. In total four factors were extracted, combining explained a total of 73.27 percent of Variation. The items with a threshold limit of $\leq .45$ were eliminated. The results of EFA and pattern matrix are in the form of Table-9.

Table 9. Pattern Matrix

\begin{tabular}{|l|c|c|c|c|}
\hline & \multicolumn{4}{|c|}{ Factors } \\
\cline { 2 - 5 } & 1 & 2 & 3 & 4 \\
\hline Education Q1 & .225 & -.084 & .656 & .033 \\
\hline Education Q2 & -.096 & -.006 & 1.043 & .005 \\
\hline Education Q3 & .169 & .069 & .690 & .003 \\
\hline Education Q6 & .804 & -.131 & .153 & -.028 \\
\hline Education Q7 & .824 & .175 & .001 & -.119 \\
\hline Education Q8 & .825 & .078 & -.036 & -.028 \\
\hline Education Q9 & .789 & -.124 & .065 & .091 \\
\hline Education Q10 & .573 & .180 & .029 & .122 \\
\hline Education Q11 & .594 & .148 & -.002 & .162 \\
\hline Education Q12 & -.027 & .051 & -.030 & .854 \\
\hline Education Q13 & .099 & .060 & .102 & .691 \\
\hline Education Q14 & .063 & .777 & -.013 & .098 \\
\hline Education Q15 & -.051 & .728 & -.010 & .192 \\
\hline Education Q16 & -.020 & .970 & -.022 & -.099 \\
\hline Education Q4 & .147 & .455 & .366 & -.074 \\
\hline Extraction Method: Principal Axis Factoring. & & & \\
\hline Rotation Method: Promax with Kaiser Normalization. & & & & \\
\hline a. Rotation converged in 7 iterations. & & & \\
\hline
\end{tabular}

After careful deliberations, the factors emerged through EFA can be streamlined in the form of a four-step model in which the factor one which constitutes variables from 1-3 can be named as Germination of Entrepreneurship. The germination can be possible by providing entrepreneurial centric educational support by offering courses focused on inculcating the entrepreneurial ability and start up capacity. 
Factor two consists the variables from 6-11; can be termed as Cultivation of entrepreneurial skills which are necessary for a successful entrepreneur by creating a culture of entrepreneurship and by offering flexible, need base and real time curriculum.

Factor three consists the variables $11 \& 12$ are named as blooming. Blooming of entrepreneurial culture can be possible by creation of entrepreneurial awareness to enhance the entrepreneurial career launching. The next factor four consists of variables 14 to 16 and variable 4 can be named as Harvesting which is the combined results of the above three steps/factors that can be possible by creating networking opportunities for startup funding.

This proposed generic model reflected in Figure-1 below can be taken as a support mechanism of entrepreneurship development among the local community by the Prince Sattam bin Abdulaziz University.

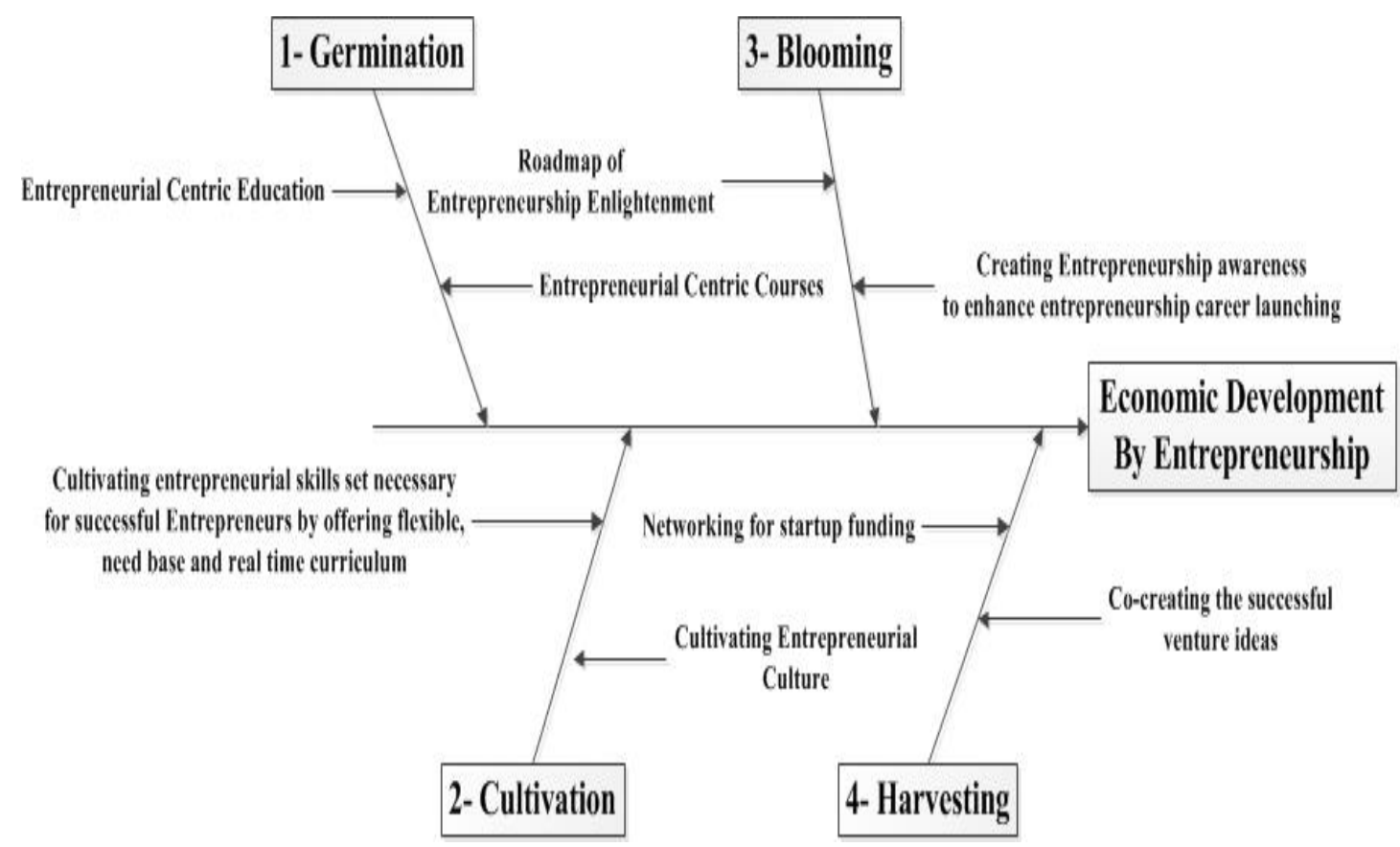

Fig.1. Generic Model of institutional support to the Local Community for entrepreneurship development

Source: Researcher's compilation

\section{Conclusion, suggestions and limitations}

The present research indicates the wider acceptability of TPB in predicting the entrepreneurial intent world-wide. The purpose of the study was twofold, (i) to investigate the entrepreneurial intent of the university students, under consideration, (ii) to chalk out the factors (educational) to be considered for institutional support by the university under study. The results provide the sufficient evidence that antecedents of TPB except subjective norm contribute significantly towards predicting the entrepreneurial intent of Saudi students. Thus our results show consistency with Ali (2016); Almobaireek and Manolova (2012) and (Iqbal et al., 2012) who found subjective norm to be the insignificant predictor of the entrepreneurial intent of Saudi students. Surprisingly these results 
The International Journal

ENTREPRENEURSHIP AND SUSTAINABILITY ISSUES

ISSN 2345-0282 (online) http://jssidoi.org/jesi/

2018 Volume 5 Number 4 (June)

http://doi.org/10.9770/jesi.2018.5.4(14)

contradict with Aloulou (2016) who found subjective norm to be the strong predictor of the intent of Saudi students.

Therefore, the findings support the previous research on TPB which reflects the importance of this model worldwide (Engle et al., 2010; Kautonen et al., 2015; Lüthje \& Franke, 2003; Shook \& Bratianu, 2010; van Gelderen et al., 2008). The findings match with the findings of Krueger et al. (2000) and (Autio et al., 2001) who found Attitude and PBC as the significant and vigorous predictor of EI but not the Subjective norm. The Demographic variables (such as gender, age, family business background, etc.) taken together along with TPB also do not seem to pose a significant impact over the antecedent of TPB but improve the prediction power of the model.

The prior application of TPB in Saudi context suggested that attitude, subjective norm and perceived behavioural control when taken together explain 33.4 percent variance in Aloulou (2016) and 40 percent in Ali (2016). However, in the present study it shows 43.2 percent.

The second section of the paper that carried out the factor analysis emerged with four important factors from a population source that do not have any specific \& formal kind of entrepreneurial education but have a bent of mind and more importantly a positive attitude towards starting new ventures and interested in playing an entrepreneurial role in future. The factors extracted by the exploratory factor analysis are emerged into a four-step generic model that can be set into the Germination of entrepreneurial seed, Cultivating entrepreneurial culture, Blooming of entrepreneurial mind and Harvesting of entrepreneurs' initiative. Saudi Arabia is the biggest market in GCC. Therefore, Universities are encouraged to have formal agreements/partnerships with the startups and new ventures facilitation centers.

Likely others one of the limitations of the study can be pointed that the results cannot be generalised as the study is particularly focussed on one region and universities of Saudi Arabia. Another limitation can be that the sample was analysed by applying only the linear approach of regression; a second generation structural approach can get more reliable and robust results.

\section{References}

Abreu, M., Demirel, P., Grinevich, V., \& Karataş-Özkan, M. (2016). Entrepreneurial practices in research-intensive and teaching-led universities. Small business economics, 47(3), 695-717. http://dx.doi.org/10.1007/s11187-016-9754-5.

Ajzen, I. (1991). The theory of planned behavior. Organizational Behavior and Human Decision Processes, 50(2), $179-211$. http://dx.doi.org/10.1016/0749-5978(91)90020-T

Ajzen, I. (2002). Perceived behavioral control, Self-Efficacy, locus of control, and the theory of planned Behavior1. Journal of Applied Social Psychology, 32(4), 665-683.

Ajzen, I., \& Fishbein, M. (2005). The influence of attitudes on behavior. The handbook of attitudes, 173, 221.

Ali, T. B. (2016). Explaining the intent to start a business among Saudi Arabian University Students. International Review of Management and Marketing, 6(2).

Almobaireek, W. N., \& Manolova, T. S. (2012). Who wants to be an entrepreneur? Entrepreneurial intentions among Saudi university students. African Journal of Business Management, 6(11), 4029-4040.

Aloulou, W. J. (2016). Predicting entrepreneurial intentions of final year Saudi university business students by applying the theory of planned behavior. Journal of Small Business and Enterprise Development, 23(4), 1142. 
Autio, E., H. Keeley, R., Klofsten, M., G. C. Parker, G., \& Hay, M. (2001). Entrepreneurial Intent among Students in Scandinavia and in the USA. Enterprise and Innovation Management Studies, 2(2), 145-160. http://dx.doi.org/10.1080/14632440110094632

Baptista, R., \& Thurik, A. R. (2007). The relationship between entrepreneurship and unemployment: Is Portugal an outlier? Technological Forecasting and Social Change, 74(1), 75-89. http://dx.doi.org/10.1016/j.techfore.2006.04.003

Birch, D. L. (1983). Job creation in the U.S. and other western nations in the 1980's. House Budget Committee taskforce on education and employment, U. S. Government Report.

Bird, B. J. (1988). Implementing Entrepreneurial Ideas: The Case For Intention. Academy of Management. The Academy of Management Review, 13(3), 442.

Bygrave, W., \& Minniti, M. (2000). The social dynamics of entrepreneurship. Entrepreneurship: theory and practice, 24(3), 25-25.

Coduras, A., Urbano, D., Rojas, Á., \& Martínez, S. (2008). The Relationship Between University Support to Entrepreneurship with Entrepreneurial Activity in Spain: A Gem Data Based Analysis. International Advances in Economic Research, 14(4), 395-406. http://dx.doi.org/10.1007/s11294-008-9173-8

Engle, R. L., Dimitriadi, N., Gavidia, J. V., Schlaegel, C., Delanoe, S., Alvarado, I., Wolff, B. (2010). Entrepreneurial intent: A twelve-country evaluation of Ajzen's model of planned behavior. International Journal of Entrepreneurial Behavior \& Research, 16(1), 35-57. http://dx.doi.org/10.1108/13552551011020063

Engle, R. L., Schlaegel, C., \& Dimitriadi, N. (2011). Institutions and entrepreneurial intent:: a cross-country study. Journal of Developmental Entrepreneurship, 16(2), 227-250.

Gertler, M. S., \& Vinodrai, T. (2005). Anchors of creativity: how do public universities create competitive and cohesive communities. Taking public universities seriously, 293-315.

Guerrero, M., \& Urbano, D. (2012). The development of an entrepreneurial university. The Journal of Technology Transfer, 37(1), 43-74. http://dx.doi.org/10.1007/s10961-010-9171-x

Iakovleva, T., Kolvereid, L., \& Stephan, U. (2011). Entrepreneurial intentions in developing and developed countries. Education + Training, 53(5), 353-370. http://dx.doi.org/10.1108/00400911111147686

Iqbal, A., Melhem, Y., \& Kokash, H. (2012). Readiness of the university students towards entrepreneurship in Saudi private university: An exploratory study. European Scientific Journal, ESJ, 8(15).

Kautonen, T., Gelderen, M., \& Fink, M. (2015). Robustness of the Theory of Planned Behavior in Predicting Entrepreneurial Intentions and Actions. Entrepreneurship Theory and Practice, 39(3), 655-674. http://dx.doi.org/10.1111/etap.12056

Khalifa, A. H., \& Dhiaf, M. M. (2016). The impact of entrepreneurship education on entrepreneurial intention: the UAE context. Polish Journal of Management Studies, 14(1), 119--128.

Khan, M. R. (2013). Mapping entrepreneurship ecosystem of Saudi Arabia. World Journal of Entrepreneurship, Management and Sustainable Development, 9(1), 28. http://dx.doi.org/10.1108/20425961311315700

Kirby, D. A. (2006). Creating Entrepreneurial Universities in the UK: Applying Entrepreneurship Theory to Practice. The Journal of Technology Transfer, 31(5), 599-603. http://dx.doi.org/10.1007/s10961-006-9061-4

Kirby, D. A., Guerrero, M., \& Urbano, D. (2011). Making Universities More Entrepreneurial: Development of a Model. Canadian Journal of Administrative Sciences / Revue Canadienne des Sciences de l'Administration, 28(3), 302-316. http://dx.doi.org/10.1002/cjas.220

Kolvereid, L. (1996). Prediction of employment status choice intentions. Entrepreneurship: Theory and Practice, $21(1), 47$.

Krueger, N. F., Reilly, M. D., \& Carsrud, A. L. (2000). Competing models of entrepreneurial intentions. Journal of Business Venturing, 15(5), 411-432. http://dx.doi.org/10.1016/S0883-9026(98)00033-0 
The International Journal

ENTREPRENEURSHIP AND SUSTAINABILITY ISSUES

ISSN 2345-0282 (online) http://jssidoi.org/jesi/

2018 Volume 5 Number 4 (June)

http://doi.org/10.9770/jesi.2018.5.4(14)

Liñán, F. (2008). Skill and value perceptions: how do they affect entrepreneurial intentions? International Entrepreneurship and Management Journal, 4(3), 257-272. http://dx.doi.org/10.1007/s11365-008-0093-0

Liñán, F., \& Chen, Y.-W. (2006). Testing the entrepreneurial intention model on a two-country sample.

Liñán, F., \& Chen, Y.-W. (2009). Development and Cross-Cultural Application of a Specific Instrument to Measure Entrepreneurial Intentions. Entrepreneurship Theory and Practice, 33(3), 593-617. http://dx.doi.org/10.1111/j.1540-6520.2009.00318.x

Lüthje, C., \& Franke, N. (2003). the 'making' of an entrepreneur: testing a model of entrepreneurial intent among engineering students at MIT. $R \& D$ Management, 33(2), 135-147. http://dx.doi.org/10.1111/1467-9310.00288

Majumdar, S., \& Varadarajan, D. (2013). Students' attitude towards entrepreneurship: does gender matter in the UAE? foresight, 15(4), 278-293. http://dx.doi.org/10.1108/FS-03-2012-0011

Matlay, H. (2008). The impact of entrepreneurship education on entrepreneurial outcomes. Journal of Small Business and Enterprise Development, 15(2), 382-396. http://dx.doi.org/10.1108/14626000810871745

McMullan, W. E., \& Long, W. A. (1987). Entrepreneurship education in the nineties. Journal of Business Venturing, 2(3), 261-275. http://dx.doi.org/10.1016/0883-9026(87)90013-9

Mustafa, M. J., Hernandez, E., Mahon, C., \& Chee, L. K. (2016). Entrepreneurial intentions of university students in an emerging economy: The influence of university support and proactive personality on students' entrepreneurial intention. Journal of Entrepreneurship in Emerging Economies, 8(2), 162-179. http://dx.doi.org/10.1108/JEEE-10-2015-0058

Nabi, G., Liñán, F., Iakovleva, T., Kolvereid, L., \& Stephan, U. (2011). Entrepreneurial intentions in developing and developed countries. Education+ Training, 53(5), 353-370.

Radwan, A.; Sakr, M. M. 2017. Review of Egypt Science and Technology System: SWOT analysis, Entrepreneurship and Sustainability Issues 5(2): 204-211. https://doi.org/10.9770/jesi.2017.5.2(3)

Saleh, W., \& Salhieh, L. (2014). An Investigation of Entrepreneurial Intention amongst Arab University Students. International Journal of Business and Management, 9(12), 197.

Schlaegel, C., \& Koenig, M. (2014). Determinants of Entrepreneurial Intent: A Meta-Analytic Test and Integration of Competing Models. Entrepreneurship Theory and Practice, 38(2), 291-332. http://dx.doi.org/10.1111/etap.12087

Schwarz, E. J., Wdowiak, M. A., Almer-Jarz, D. A., \& Breitenecker, R. J. (2009). The effects of attitudes and perceived environment conditions on students' entrepreneurial intent: An Austrian perspective. Education \& Training, 51(4), $272-291$. http://dx.doi.org/10.1108/00400910910964566

Shook, C. L., \& Bratianu, C. (2010). Entrepreneurial intent in a transitional economy: an application of the theory of planned behavior to Romanian students. International Entrepreneurship and Management Journal, 6(3), 231-247. http://dx.doi.org/10.1007/s11365$\underline{008-0091-2}$

Støren, L. A. (2014). Entrepreneurship in higher education: Impacts on graduates' entrepreneurial intentions, activity and learning outcome. Education \& Training, 56(8/9), 795-813. http://dx.doi.org/10.1108/ET-06-2014-0070.

Thurik, R. (2003). Entrepreneurship and Unemployment in the UK. Scottish Journal of Political Economy, 50(3), 264-290. http://dx.doi.org/10.1111/1467-9485.5003001.

Turker, D., \& Sonmez Selcuk, S. (2009). Which factors affect entrepreneurial intention of university students? Journal of European Industrial Training, 33(2), 142-159. http://dx.doi.org/10.1108/03090590910939049.

Van Gelderen, M., Brand, M., van Praag, M., Bodewes, W., Poutsma, E., \& van Gils, A. (2008). Explaining entrepreneurial intentions by means of the theory of planned behaviour. Career Development International, 13(6), 538-559. http://dx.doi.org/10.1108/13620430810901688 
The International Journal

ENTREPRENEURSHIP AND SUSTAINABILITY ISSUES

ISSN 2345-0282 (online) http://jssidoi.org/jesi/

2018 Volume 5 Number 4 (June)

http://doi.org/10.9770/jesi.2018.5.4(14)

\section{Aknowledgements}

We are grateful to the Deanship of Scientific Research at Prince Sattam Bin Abdulaziz University for financing this study under the research project \# 2015/02/4862.

Dr. Mohammad Naushad is the Assistant Professor of Business and Management at College of Business Administration, Prince Sattam Bin Abdulaziz University, KSA. He has worked on the various topics of entrepreneurship, teaching, learning and educational quality issues. He is currently working on multiple issues of entrepreneurship studies.

ORCID ID: https://orcid.org/0000-0003-4421-3422.

Dr. Mohammad Rishad Faridi is the Assistant Professor of Marketing at College of Business Administration, Prince Sattam Bin Abdulaziz University, KSA. He has worked on the various topics of marketing and teaching and learning aspects.

ORCID ID: https://orcid.org/0000-0003-2733-0731

Dr. Syed Abdul Malik is Faculty, Department of Finance, College of Business Administration, Prince Sattam Bin Abdul Aziz University, Al-Kharj, Saudi Arabia. His research interests include Finance, Banking, etc.

ORCID ID: https://orcid.org/0000-0001-5593-7405

Copyright (C) 2018 by author(s) and VsI Entrepreneurship and Sustainability Center

This work is licensed under the Creative Commons Attribution International License (CC BY).

http://creativecommons.org/licenses/by/4.0/

c) (7) Open Access 